\title{
Environmental changes and temporal distribution of order Rodentia in North-East Brazil, and its link to the El Niño Southern Oscillation and drought in the region
}

\author{
G. Cruz Santos \\ Department of Economics and Social Science, \\ Polytechnic University of Valencia, Spain
}

\begin{abstract}
Between 1978 and 2010 in the Low San Francisco Sergipano ("LSFS") NorthEast Brazil ("NEB") region, there have been outbreaks of rodent plagues with an irregular temporal scale but in the same spatial scale, where rats have attacked the floodplain rice fields. Rats constitute a serious problem, insofar as they affect rice growing in this region causing massive economic losses. "El Niño" (EN) has a significant impact on animal communities and its effects on NEB are most often associated with years of drought throughout that region, which tested serious environment changes in the 1970s. The genera and species identified in the paper are Holochilus sicureus, which is predominant in the LSFS, Oryzomys sublavus, Rattus spp., and Nectomys sp. This comparative study of the plague years suggest that the temporal scale for the rat plague is related to the El Niño/Southern Oscillation (ENSO) years and climatic conditions in the dry season in the NEB region.

Keywords: floodplain, Holochilus, Low San Francisco Sergipano, Neópolis, Propriá, rodent outbreak.
\end{abstract}

\section{Introduction}

The index Southern Oscillation Index (SOI) [1] and its effects have often been linked with significant changes in animal behaviour [2-6]. Chilean scientists have shown the link between the El Niño Southern Oscillation (ENSO) event, the phenomenon known as "blooming desert" and the "rodent irruptions" ("ratadas") 
[5]. The "ratadas" have been associated with the ENSO event in the semi-arid regions of different South American countries such as Argentina, Bolivia, Brazil, Chile, Paraguay, Peru and Uruguay [5]. The effects of this oceanic and atmospheric coupling event referred to as SOI/ENSO have a big impact in the North-East Brazil (NEB) with the El Niño (EN) causing dry season with belowaverage precipitation, and La Niña (LN) contributing with precipitation [7-11]. Low San Francisco Sergipano (LSFS) is one of the sub-regions within NEB, and it has long been held as a natural example of interaction between river and floodplain systems. This sub-region actually underwent major environmental changes in the 1970s with a modification of the San Francisco (SF) river course triggered by the construction of the Sobradinho dam and reservoir [12-15]. As a result of this, the natural rice-growing floodplain areas were changed to an irrigated perimeter. Ever since the irrigated perimeter began operating in 1977, rodent outbreaks ("ratadas") have become usual on these floodplains [16]. This is a comparative study focused on the temporal scale between years of the ENSO event and rodents outbreak. It is suggested that rat plague is related to the years of ENSO; and the climate conditions in NEB during the dry season. This study makes a review of the literature linking ENSO events and "ratadas" in this region, and analyses the correlation between anomalies from oceanic-atmospheric regions ("OAR") and precipitation in the rice-growing floodplains in the LSFS for the years with rodent outbreaks.

\subsection{Area of study and data}

The PIB is a floodplain with a total area of 647.7 hectares. This region has an average annual temperature of $25.5^{\circ} \mathrm{C}$ and its mean annual precipitation (MAP) of $1.555 \mathrm{~mm}$. The climate is sub-humid according to Thornthwait with two clearly defined seasons, resulting in a wet and relatively dry and warm [13-15]. In Propriá, the climate is "megathermic" semi-arid with MAP of $806.01 \mathrm{~mm}$ and an average annual temperature of $26.1^{\circ} \mathrm{C}$ [17]. Propriá is included within the semiarid tropical zone and Neópolis within the sub-humid zone [13, 17].

In order to determine the correlation between the ENSO events, climatic conditions of the LSFS and rodent outbreaks, we analyse the monthly precipitation in a range of 10 non-sequential years in the same temporal scale in two different geographical zones of the LSFS floodplains areas which had recorded rat plagues: Propriá and Irrigated Perimeter Betume ("PIB")-Neópolis in the north NEB ("nNEB"). Their rainfall was compared with the respective monthly anomalies for OAR categories in the Equatorial Pacific Ocean for the SOI [18] and the Niños Regions ("NR"): n1+2, n3, n4, n34 [19]. The most common correlation or predictability measurement, Pearson's coefficient $(r)$, was introduced to assess the monthly precipitation anomalies of LSFS and OAR. The significance of the relationship was expressed in the probability value $p$ at a linear correlation significance level of $p \leq 0.05$ and $p \leq 0.01$ (*95\% and **99\%). The software programme SPSS, version 19.0, was used for the statistical analysis. The comparison between the temporal scale characterised by the ENSO event, was checked against the National Oceanographic and Atmospheric Administration (NOAA) [20]. LSFS monthly precipitation data were provided by INMET and 
CMRHSE [21] for the years 1978, 1982, 1983 and 1988 in Propriá 10 12'49" S and $36^{\circ} 50^{\prime} 28^{\prime \prime}$ ' [17], and Ascondir Station in Betume-Neópolis $10^{\circ} 17^{\prime}$ and $10^{\circ}$ 24' S and 36 $36^{\circ} 3545 \mathrm{~W}$ [22] for the years 1993, 1998, 1999, 2005, 2009 and 2010. The 63 rice-growers from Betume were surveyed about the rodent plague in the LSFS floodplains before the environmental changes with one question: "Were there "Ratadas" before the PIB came into operation?" In this study, when $\mathrm{MAP}<800 \mathrm{~mm}$, it is considered as years with much lower than mean annual precipitation (MLMAP) [23].

\section{Results and discussion}

In this study it was confirmed that: (a) the rat plague has been an irregularly occurring natural phenomenon in the LSFS floodplains; (b) an occurrence of rodent outbreak with losses for the growers of the flooded rice fields happened for the first time in 1978 after the environmental changes in the region; (c) in the LSFS 3 types of environmental changes were identified: (a) a physical change in the course of the SF River as a result of the construction of the Sobradinho dam in 1973 , and it coming into operation in 1977; (b) changes in the use of the land with it traditional production system changing to irrigation system, and from one annual harvest to two; (c) and the three naturally occurring different land use stages during the year (river-floodplain, flooded rice-fields, and pasture) were reduced to solely rice-growing.

Of the 63 rice growers surveyed, $69.84 \%$ of them answered 'no' to the question about whether the plague had occurred prior to the environmental changes. The remaining $30.16 \%$ of rice-growers had no knowledge of the period prior to the environmental changes. "Ratadas" were actually observed in the rice-growing LSFS floodplains in 10 years of the last three decades since PIB came into operation (namely:1978, 1982, 1983, 1988, 1993, 1998, 1999, 2005, 2009 and 2010), table 1.

Table 1: Temporal scale for rodent outbreaks and ENSO event.

\begin{tabular}{|c|c|c|c|c|c|}
\hline Plague & EN & LN & n-NEB & LSFS & $\begin{array}{c}\text { LSFS } \\
\mathrm{mm}\end{array}$ \\
\hline 1978 & weak & - & rainy & HMAP & 1.127 .4 \\
\hline 1982 & strong & - & rainy & MLMAP & 780 \\
\hline 1983 & strong & weak & drought & MLMAP & 484 \\
\hline 1988 & strong & strong & rainy & MLMAP & 475 \\
\hline 1993 & neutral & neutral & drought & MLMAP & 486 \\
\hline 1998 & strong & moderate & drought & LMAP & 998.1 \\
\hline 1999 & moderate & moderate/strong & rainy & LMAP & 1.035 .8 \\
\hline 2005 & weak & weak & rainy & LMAP & 1.460 .1 \\
\hline 2009 & moderate & weak & rainy & HMAP & 1.711 .7 \\
\hline 2010 & moderate & strong & rainy & HMAP & 1.715 .6 \\
\hline
\end{tabular}

Table based on [16, 20-22, 27, 28]. 


\subsection{EI Niño events and precipitation in the n-NEB and LSFS}

In relation to the climatic conditions in the n-NEB the review of the literature has shown years with rainy seasons and severe drought in the n-NEB, table 1 . The crossing point between the anomalies found in LSFS through the data corresponding to Propriá and PIB was identified as:(a) years with much lower than the mean annual precipitation (MLMAP) in 1982, 1983, 1988, and 1993; (b) years with a low mean annual precipitation (LMAP) in (1998, 1999 and 2005) and (c) years with a high mean annual precipitation (HMAP) - higher than the usual precipitation level in the LSFS region in 1978, 2009 and 2010 in table 1.

\subsubsection{Statistical analyses between anomalies in OARs and LSFS}

The correlation analysis of monthly anomalies between TSM (Temperature Sea Marine) of OARs and precipitation in LSFS floodplains identified four climatic conditions: (a) Association of correlations between SOI-NR $r<0$; NR-LSFS $r<0$ and SOI-LSFS $r>0$ in 1978 (EN-weak), and in 1982, with the EN (weak and strong) events in tables 1 and 2; (b) SOI-NR $r<0$, NR-LSFS $r>0$ and SOI-LSFS $\mathrm{r}<0$ in 1983 with EN and LN (strong-weak) events; and in 1993 (a neutral year for the ENSO event in tables 1 and 2; (c) SOI-NR $r<0$, NR-LSFS $r>0$ and SOI-LSFS $\mathrm{r}>0$ in 1988 (EN strong; LN strong), 1998 (EN strong; LN moderate), tables 1 and 2; (d) SOI-NR $r<0$, NR-LSFS $r>0$ and SOI-LSFS $r<0$ with years with both EN and LN episodes: in 1999 (EN-moderate and LN moderate/strong), in 2005 (EN weakLN weak), 2009 (EN-moderate; LN-weak) and 2010 (EN moderate-LN strong) in table 1. Save for 1993, all the other years showing an occurrence of the plague were years of ENSO events.

2.1.1.1 Rodent outbreaks The plague first occurred in 1978, with neither the genus nor species being identified; in 1982-1983, rats were identified as Holochilus sp., Rattus spp. and Kerodon rupestris; 1988 had rodent irruption in the LSFS with neither the genus nor species being identified; in 1993, as Holochilus sciureus and Oryzomys sublavus; in 1998, the damage was caused by Holochilus sciureus; and in 1999, they were identified as Holochilus sciureus, Nectomys sp., and Rattus spp. by means of data collected in the field; finally, the damage was attributed to Holochilus sciureus in 2005, 2009 and 2010.

According to Santos [16], rodent outbreaks in the LSFS region result from the environmental impact caused by the changes experienced in the region. Before the environmental changes, during higher-water stages the river was a corridor for the aquatic species that entered the floodplains, thus functioning as a natural barrier against terrestrial animals such as infestations, and the productive system of this period had fishing as its basis. Instead, when the water returned to river, the lagoons became rice-growing fields with one annual harvest, and when the water level fell, the floodplains became grazing pastures. The traditionally established related to land use in this floodplain agro-ecosystem was almost lost.

Of the 63 rice-growers who answered the question posed, $69.84 \%$ corresponding to those who lived in this region when the environmental changes took place - linked plague occurrence since 1978 to the introduction of PIB for 
Table 2: Correlation analysis between TSMs of OARs and LSFS.

\begin{tabular}{|c|c|c|c|c|c|}
\hline $\begin{array}{c}\text { Years: } \\
\text { TSMs/OARs } \\
\text { and }(\mathrm{r})\end{array}$ & $\mathrm{n} 1+2$ & n3 & $\mathrm{n} 4$ & n34 & $\begin{array}{l}\text { SOI- } \\
\text { LSFS }\end{array}$ \\
\hline $\begin{array}{c}1978 \\
\text { SOI-NR }\end{array}$ & $-.597^{*}$ & $-.641^{*}$ & -.315 & $-.606^{*}$ & .486 \\
\hline NR-LSFS & $-.694^{*}$ & $-.762^{* *}$ & -.302 & -.476 & \\
\hline $\begin{array}{c}1982 \\
\text { SOI-NR }\end{array}$ & $-.882^{* *}$ & $-.862^{* *}$ & .312 & $-.863^{* *}$ & .171 \\
\hline NR-LSFS & -.432 & -.424 & -.300 & -.359 & \\
\hline $\begin{array}{c}1983 \\
\text { SOI-NR }\end{array}$ & -.109 & $-.684^{*}$ & $-.720^{* *}$ & $-.808^{* *}$ & -.308 \\
\hline NR-LSFS & .256 & .163 & .196 & .141 & \\
\hline $\begin{array}{c}1988 \\
\text { SOI-NR }\end{array}$ & -.569 & $-.631^{*}$ & $-.742^{* *}$ & $-.730^{* *}$ & .026 \\
\hline NR-LSFS & .102 & .296 & .188 & .279 & \\
\hline $\begin{array}{c}1993 \\
\text { SOI-NR }\end{array}$ & -.459 & -.257 & .222 & -.206 & -.289 \\
\hline NR-LSFS & .251 & .091 & -.141 & .055 & \\
\hline $\begin{array}{c}1998 \\
\text { SOI-NR }\end{array}$ & $-.801^{* *}$ & $-.924^{* *}$ & $-.905^{* *}$ & $-.926^{* *}$ & .133 \\
\hline NR-LSFS & .375 & .155 & .193 & .100 & \\
\hline $\begin{array}{c}1999 \\
\text { SOI-NR }\end{array}$ & .296 & -.300 & $-.776^{* *}$ & -.413 & $-.681^{*}$ \\
\hline NR-LSFS & -.500 & .126 & $.800^{* *}$ & .346 & \\
\hline $\begin{array}{c}2005 \\
\text { SOI-NR }\end{array}$ & -.089 & -.269 & -.269 & -.159 & -.187 \\
\hline NR-LSFS & .463 & .512 & -.092 & .213 & \\
\hline $\begin{array}{c}2009 \\
\text { SOI-NR }\end{array}$ & -.402 & $-.683^{*}$ & $-.716^{* *}$ & $-.716^{* *}$ & -.248 \\
\hline NR-LSFS & .527 & .118 & .003 & .006 & \\
\hline $\begin{array}{c}2010 \\
\text { SOI-NR }\end{array}$ & $-.691^{*}$ & $-.862^{* *}$ & $-.842^{* *}$ & $-.880^{* *}$ & -.516 \\
\hline NR-LSFS & $.706^{*}$ & $.771^{* *}$ & $.757^{* *}$ & $.761^{* *}$ & \\
\hline
\end{tabular}

rice growing, according to $[24,25]$. The rodent outbreak appears as a natural and irregular disturbance in NEB [26], it suggests that an irregular outbreak of "ratadas" could be normal in this region in years with strong ENSO events (EN and LN).

Since the first confirmed rodent outbreak occurrence in the LSFS region in 1978 , of the 12 years with strong ENSO events (1982-1983, 1987-1988, 19971998 (EN); 1988-1989, 1999-2000 and 2010-2011 (LN) [20], six of them (4 strong EN and 3 strong LN) were noted for plagues in LSFS (1982-1983, 1988, $1998,1999,2010)$ in table 1 . Of these six years, three "ratadas" occurred in years 
of extreme drought in the NEB region (1982, 1983 and 1988) [27, 28] and in 1993 been a year of extreme drought with neither ENSO event being identified, table 1 .

Mares et al. [29] claim that animals from semi-arid areas are generally not well anatomically and physiologically adapted to bear the climate conditions which are typical of such periods. These animals could use microhabitats and shelters during drought periods, possibly developing their adaptation mechanisms as a solution in order to offset their physiological deficiencies [30]. Santos [16, 31] associated years of ENSO events with years of "ratadas" in LSFS. All of the above suggests that, during these very warm periods resulting from ENSO in LSFS semi-arid zones, these mammals seek refuge in the irrigated rice fields due both to the abundance of food and water, and the better temperature conditions. Furthermore, rice fields serve as a habitat for wild species and other animals, and riverfloodplain as systems which cannot be separated $[32,33]$.

In relation to ENSO years, the results obtained from crossing point between the anomalies for OARs and LSFS were identified as: (a) SOI-LSFS $\mathrm{r}<0$ (1983MLMAP, 1993-MLMAP, 1999-LMAP, 2005-LMAP, 2009-HMAP and 2010HMAP) with their respective precipitation levels, tables 1 and 2; (a.1) SOI-LSFS r>0: 1978-HMAP, 1982-MLMAP, 1988-MLMAP and 1998-LMAP; and (b) NRLSFS with $r<0$ respectively for each region with data in (1978 and 1982) with (HMAP and MLMAP); and (b) NR-LSFS $r>0$ in years (1983-MLMAP, 1988MLMAP, 1993-MLMAP, 1998-LMAP, 1999-LMAP, 2005-LMAP, 2009-HMAP and 2010-HMAP respectively in tables 1 and 2. According to Dos Santos et al. [34], if SOI-LSFS $r>0$, then there would be precipitation in the NEB and, conversely, a drought season would occur when NR-LSFS with $r>0$. However, it is possible for us to confirm HMAP in years with NR-LSFS for $r>0$ in 2009 and 2010.

With the exception of Rattus spp. [35], all the other confirmed genera and species identified by this study - in tune with the results obtained in other previous works - are native to the caatinga ecosystem in the NEB region. The genera and species identified in the study area according to the years of rodent outbreaks were: Holochilus spp., Kerodon rupestris and Rattus sp. [36]; Oryzomys sublavus and Holochilus sciureus [37], and Nectomys sp., Rattus spp. and Holochilus sciureusin [16]. Holochilus sciureus is an autochthonous and predominant specie in the LSFS [37], and it is the most tropical rodent pest in South America [38]. The LSFS floodplains are a geographical zone situated between the coastline and the 'caatinga' (semi-arid ecosystem) in the NEB [39], and Junk et al. [40] claim that plenty of organisms colonise this natural ecosystems and adapt to them, equipping themselves to survive during periods of drought.

There are two major natural resources that mark the Brazilian North-East region: the climate and the SF River, both of which have shaped major environmental, social and economic condition and decision in this region. It can thus be assumed that LSFS floodplain offers far less natural barriers after the environmental changes experienced in this region, with the ENSO event coming to exert a much larger influence, which in turn resulted in an increase of rodent outbreaks in the floodplains rice fields, with the subsequent considerable losses suffered by rice growers. 
Finally, this study has shown that: (a) "ratadas" are a natural occurrence in semi-arid NEB zones, and they appear as a disturbance in LSFS floodplains as a result of the climatic condition in the region; (b) a strong link exists between the temporal scale for the ENSO event and the "ratadas" identified in different LSFS spatial scale; (c) in the specific case of the spatial scale examined here, only in one year (1993) was the association between the ENSO event and the "ratadas" not linked to that ENSO event-but severe drought occurred in the NEB region; (d) the temporal scale analysed for rodent outbreaks identifies years of ENSO events with MLMAP (drought), years with LMAP (below average precipitation) and years with heavy rains - HMAP (higher than usual precipitation) - in LSFS; (e) years with strong ENSO events were noted for drought in the NEB region with MLMAP or LMAP in the LSFS. On the whole, the study confirms the existence of a significant link between rodent outbreaks and years with ENSO, LMAP and MLMAP events in LSFS, and drought in the NEB.

\section{References}

[1] Aceituno, P. El Niño, the Southern Oscillation, and ENSO: confusing names for a complex ocean-atmosphere interaction. Bull. Amer. Met. Soc., 73, pp. 483-485, 1992.

[2] Retana, J., Solera, M., Solano, J. Efecto de la variabilidad climática sobre la Fluctuación poblacional de la rata cañera (Sgmond hispidus) en cañas, Guanacaste. Taboga: Instituto Meteorologico Nacional Gestion de Desarrollo Hernández Alvarez Ingenio Taboga Manejo de Plagas, p. 11, 2000

[3] Lima M., Marquet P.A, Jaksic, F.M. El niño events, precipitation aprrens, and rodent outbreak are statistically associated in semi-arid Chile, Ecography 22, pp. 213-218, 1999.

[4] Holmgren, M., Scheffer, M., Ezcurra, E. et al. El Niño effects on the dynamics of terrestrial ecosystems. Review TRENDS in Ecology \& Evolution, (16)2, 2001.

[5] Jaksic, F.M. The multiple facets of El Niño/Southern Oscillation in Chile. Rev Chil de Hist Nat, 71, pp. 121-131, 1998.

[6] Jaksic, F.M., Lima M. Myths and facts on ratadas: bamboo blooms, rainfall peaks and rodent outbreak in South American. Austral Ecology, p. 2, 2003.

[7] Alves, J.M.B., Campos, J.N. B., Souza, E.B. de et al. Produção agrícola de subsistencia no Estado do ceará com ênfase aos anos de ocorrência de El Niño e la Niña. Revista Brasileira de Agromeoteorologia Santa Maria, (6)2, pp. 249-256, 1998.

[8] Freire, J.L. M., Lima, J.R.A., Cavalcanti, E.P. Análise de aspectos meteorológicos sobre o Nordeste do Brasil em anos de El Niño e La Niña. Revista Brasileira de Geografia Física, (3), pp. 429-444, 2011.

[9] Bezerra, D., Filho, M.F. G., Servain, J. Avaliação do impacto de eventos climáticos extremos nos océanos Pacífico e Atlântico sobre a estação chuvosa no Nordeste do Brasil. Revista Brasileira de Meteorologia, (26)2, 297-312, 2011. 
[10] Moura, G.B. de A., Aragão, J.O.R. de. Relação entre a precipitação do leste do Nordeste do Brasil e a temperatura dos oceanos. Revista Brasileira de Engenharia Ambiental, (13)4, pp. 462-469, 2009.

[11] Melo, J.C. de. O fenómeno El niño e as secas no Nordeste do Brasil. Raízes, Ano XVIII, (20), pp. 13-21, 1999.

[12] Codevasf. Projeto de emergencia: pequeñas várzeas, Baixo São Francisco. Brasília: Ministério do Interior/SIRAC, p. 3, 1976.

[13] Codevasf. Estado de Sergipe/Serviço de Extensão Rural/ANCARSE. Plano de ação para os vales úmidos do Baixo São Francisco. SUVALE/ANCARSE, Aracaju, 1972.

[14] Codevasf. Relatório de comissão construída através da determinação 001/83 da $4^{\mathrm{a}}$ DR, para avaliação de lotes do Projeto Betume Sequeiro: Aracaju, Fev, 1983.

[15] Codevasf. Ficha técnica do Perímetro Irrigado Betume, 1999, Aracaju: SEPRE/CODEVASF. 4 ${ }^{\text {a }}$ Superitendência Regional, pp.11, 1999.

[16] Santos, G.C. Relação sociedade-natureza e a problemática da infestação de roedores (ratos) em área irrigada cultivada com arroz (Oriza sativa L.) no baixo São Francisco sergipano. Tesis de Maestría no publicada. Núcleos de Estudos do Semi-Arido-NESA, Universidade Federal de Sergipe: Aracaju, p. 175, 2000.

[17] Bomfim, Luis F.C.; Costa, I.V.G. da; Benvenuti, Sara M. P. Diagnóstico do municipio de Propriá. Projeto cadastro da infra-estructura hídrica do Nordeste- Estado de Sergipe: Aracaju, 2002.

[18] NOAA, http://www.cpc.ncep.noaa.gov/data/indices/soi.

[19] NOAA, http://www.cpc.ncep.noaa.gov/data/indices/ersst3b.nino.mth.ascii.

[20] NOAA, http://ggweather.com/enso/oni.htm.

[21] INMET-CMRHSE, http://www.agritempo.gov.br/agroclima/sumario?uf $=\mathrm{SE}$.

[22] ASCONDIR-Estación Meteorológica: Platô de Neópolis. Dados climáticos mensuales: 1998, 1999, 2005, 2009, 2010.

[23] Junio, J. de S.P. Nova delimitação do semiárido brasileiro. Biblioteca Digital da Câmara dos Deputados, p. 25, 2007.

[24] Barros, H.O. Monteiro de. Modernização agrícola autoritária e desestruturação do ecosistema: o caso do Baixo São Francisco. Cad. Est. Soc., Recife, (1)1, pp. 97-113, 1985.

[25] Cruz, P.F.N. da. Ocorrências de danos causados por roedores, pragas do cacueiro na Bahia: Brasil. Revista Theobroma, 1983.

[26] Paiva, P.M, Campos E. Fauna do nordeste do Brasil conhecimento popular. Banco do Nordeste do Brasil: Fortaleza, 1995.

[27] Aragão, J.O.R. de. A previsão da precipitação no norte do nordeste do Brasil para o periodo chuvoso de fevereiro a maio: os anos: 1997/98. Secretaria de Ciência, Tecnologia e Meio Ambiente: Departamento de Hidrometeorologia, p. 4, 1998.

[28] Souza, I.F. de, Aguiar, N.A. de O. In: Congresso Brasileiro de Agrometeorologia. Comportamento da precipitação, pluviométrica durante 
o período chuvoso em anos de Enos no Estado de Sergipe. Florianópolis: Anáis Florianópolis/SC, 1999.

[29] Mares, M.A., Willig, M.R., Lacher Jr., T.E. The Brazilian caatinga in South American zoogeography: tropical mammals in a dry region. $J$. Biogeography, 12, pp. 57-69, 1981.

[30] Strein, K.E. Ecology of small mammals in the semiarid Brazilian caatinga. V. Agonistic behavior and overview. Ann. Carnegie Museum, 51, pp. 345369, 1982.

[31] Santos, G.C. Variación y proporción de varianza de (ROA) regiones océano atmosféricas y $(\mathrm{AH})$ áreas húmedas en años ENOS con o sin ocurrencia de "ratadas", el caso del (BSFS) Bajo San Francisco Sergipano, (NEB) Nordeste de Brasil. Revista Digital de Medio Ambiente "Ojeando la Agenda", 24 Jul, 2013.

[32] Tadeo, A.J.P., Martinez, E.R, Estruch, V. Farming efficiency and the survival of valuable agro-ecosystems: A case study of rice farming in European Mediterranean Wetlands. Open Environmental Sciences, 3, pp. 42-51, 2009, 1876-3251.

[33] Junk, W.J., Wantzen, K.M. The flood pulse concept: new aspects, approaches and applications-an update.

[34] Dos Santos, E.P., Filho, I.M.C., De Brito, J.I.B. Influência do Indice de Oscilação Sul (IOS) e anomalía do niño sobre as chuvas no Nordeste Brasileiro.

[35] Moojen. J. Os roedores do Brasil. Rio de Janeiro, 1952.

[36] Elías, D.J. El problema de roedores en el proyecto de riego del bajo San Francisco. Status e recomendações (informe final), 1983.

[37] Sergipe, Servicio de vigilância sanitária regional de. Projeto para controle de roedores no Estado de Sergipe, 1995.

[38] Eiris G.C., Barreto G.R. Home range of marsh rats, Holochilus sciureus, a rodent pest in rice fields of Venezuela. Interciencia, (34)6 Jun, pp. 400-404, 2009. versión imprensa ISSN 0378-1844.

[39] Santos, A.F., Andrade, J.A. (coord.). Delimitação e regionalização do Brasil semi-árido Sergipe, Aracaju: UFS, 1992.

[40] Junk, W.J, Barley, P.B.; Spark, E. The flood pulse concept in riverfloodplain systems. Symposium. Can. Spec. Publ. Fish. Aquat. Sci, p. 106, 1989. 